\title{
MOBILITY AS A SUPPORT STRATEGY: LINKED LIVES THROUGH THE LIFE COURSE AMONG EASTERN EUROPEANS IN SPAIN
}

This article examines the role of mobility in the creation of support strategies of Eastern Europeans (EEs) in Spain. It emphasizes the relational linkages of mobility and shows how strategies of linked-lives are constructed and maintained over the life-course. Drawing on 52 in-depth interviews with EEs (Romanians and Bulgarians) who practice mobility to and from Spain, this article makes two contributions. First, it expands the concept of linked-lives across the life-course in mobility. Second, it highlights mobility as a support strategy to show how EE mobile children, through their movement, assist their parents both in their origin countries and in Spain. I argue that mobility articulates and harmonizes multiple practices of support strategies that link people's lives in different ways: (a) mobility as a strategy to support parents in old age; (b) mobility as a family livelihood strategy; and (c) mobility as a strategy of gratitude and family reunification. The conclusions highlight the need to integrate mobility as a support strategy into the study of global mobility.

Keywords: mobility; mobile children; linked-lives; support strategy; life-course; Eastern

Europeans

\section{Introduction}

The ‘new mobilities paradigm' (Sheller and Urry, 2006) has led to a plethora of research that tends toward a view of human mobility as a crucial phenomenon in the XXI century (Schapendonk et al., 2018; Kwan and Schwanen, 2016; Adey et al., 2013; Cresswell, 2006). While the wide geographical literature on mobility has focused on how individuals and families organize their lives in relation to others (Moskal, 2015; Lulle, 2014; Bailey, 2009), the relationships between life-course stages, transnational parenting and well-being (Visser et al., 2015; Willis and Yeoh 2002), transnational kinship (Hoang et al., 2012), family linkages, and the use of mobility and parental involvement with children (Hank, 2010), the importance of the mobile children's role in supporting their parents in the context of mobility has not yet been analyzed. 
This paper contributes to the geographical literature of mobility, highlighting the support strategies that mobile migrants offer their parents so that the latter may cope with the economic crisis affecting the family unit. Within the framework of this research, I conceptualize mobility as a fundamental part of the wider family strategy of capital accumulation, involving migration, movement, connectivity, and transnational household arrangements. Mobility is thus employed here as a broad concept that intertwines physical movement across borders in time-space, strategies, experiences and decisions of mobile people, as well as feelings, social imaginaries and interpretations of meaning.

Building on the recent geographical studies of mobility (Schapendonk et al., 2018; Moret, 2017; Findlay et al., 2015; Coulter et al., 2012) and through original analysis, the article examines linked-lives through the intergenerational relationship, revealing the role of mobility in the creation of support strategies among Eastern Europeans (EEs) in Spain. What is the impact of mobility on individuals' relationships and on family lives? How are mobility support strategies created and how do they affect both the lives of parents and those of mobile individuals?

Taking the relationship between life-course and linked lives as a central concern (Findlay et al., 2015; Bailey, 2009) and based on 52 in-depth interviews with EEs (Romanians and Bulgarians) in Spain, the article analyzes how the linked lives of lower-middle class mobile migrants are situated in time-space across the life-course. It is important to note that, while this research focuses on mobile people -including the mobility of their children-, in the context of the migration of EEs to Spain, there is also a group for whom the argument of mobility does not apply. These are people whose lives are no longer mobile and whose children do not practice mobility.

In aiming to contribute to the emerging critical question of linked-lives from the mobility perspective, I highlight 'mobility as a support strategy' to show how mobile migrants, through 
their movement, assist their parents both in their origin countries and in the host country. I argue that mobile individuals construct support strategies through their ability to use their resources and skills and to adapt them to the changing environment of mobility, taking advantage of opportunities to pursue their objective, that is, to sustain their parents' lives.

In line with Findlay et al., (2015, p.391), who highlighted that 'the linked-lives perspective recognizes mobility as relational' between people of the same family, and analyzing the interaction between individual mobility and the family unit (Carswell and De Neve, 2013; Waters, 2005), my aim is to emphasize relational linkages of mobility and to show how strategies of linked-lives are constructed and maintained. In order to understand the creation of support strategies in mobility, I highlight the enlargement of the EU border and the integration of Romania and Bulgaria into the EU (2007), which favored the free movement of its citizens. Both, openness and integration helped mobile citizens to create several types of mobility strategies to support their families and thus to link their lives more closely throughout their life-course (Marcu 2015a). I show how EEs, who practice mobility to and from Spain, from the migration pioneers of the 1990s to the young people of the second generation, assist their parents both in their origin countries and in Spain.

Unlike other groups of EEs -Poles, Slovaks or Lithuanians- who moved to EU countries such as the UK or Germany, Romanians and Bulgarians migrated for the most part to Spain (and Italy) to improve their income and life conditions, encouraged by the opportunity of work in the construction sector, the favorable climate, the lower cost of living, but also taking advantage of the common language roots-in the case of Romanians. They found employment more easily in the nineties, which favored the creation of strong social networks (Marcu, 2015b). The EU economic crisis, which mainly affects Spain, is increasingly reflected in the precarious employment faced by EE immigrants. Despite having qualified vocational training (some of them had even improved their jobs), those who arrived in Spain in the 90s and at the 
beginning of the 2000s, who are currently around 50 years of age, and working for the most part below their level of education, do not commonly embark on the roads of mobility in the competitive EU labor market. They usually move between their countries of origin and Spain often dealing with precarity. This unstable situation has affected their living conditions and forced their educated children to intensify temporary EU mobility in search of opportunities for professional development (Marcu, 2015a).

I argue that both the Spanish/EU socio-economic context and the personal and professional circumstances of EEs who practice mobility -to find work or to study overseas- produce different strategies to support their parents, and in doing so maintain the family unit. The paper thus puts families center stage, conceptualizing them as bundles of interconnected lives. Consequently, this study embraces and contrasts the different ways in which EEs choose mobility and the diverse manners in which they support their parents. I argue that each stage of the children's mobility coincident with the life-course has a different model of supporting their parents. The strategies expressed by the respondents which are: (a) mobility as a strategy to support parents in old age, (b) mobility as a family livelihood strategy; and (c) mobility as a strategy of gratitude and family reunification represent the main thematic findings of the paper.

After outlining the theoretical framework, I briefly present the characteristics of EEs in Spain. I then explain the methodology used, and analyze the interviews with individuals to highlight how mobility is used as a support strategy. The conclusions emphasize the need to integrate mobility as a support strategy into the study of global mobility, during the life-course.

\section{Mobility as a support strategy across the life-course}


This article examines the role of mobility in the creation of support strategies of EEs in Spain. It analyzes how linked-lives is connected to mobility during the life-course, characterized as 'a sequence of socially defined events and roles that the individual enacts over time' (Giele and Elder, 1998, p. 22). It draws on the new mobility research (Schapendonk, 2018; 2015; Findlay et al., 2015; Bailey, 2009), advancing critical inquiries on life-course, linked-lives, mobility and intergenerational relationships.

To conceptualize mobility as a support strategy in the family context, I start from the wide concept of 'transnationalism', which has risen as a transnational field where migrants on the move for opportunities of work or study frame new relationships with family in their home country and beyond (Glick Schiller et al., 1995). In this context, it is noted that on the one hand, geographical research has produced rich empirical studies on the relationship between separation and the organization and negotiation of family relationships and practices (Thomas et al., 2017; Collins, 2015). On the other hand, the geographical life-course approach is specifically effective for asking about the aspects of life-course stages at a time when, in a world on the move, migrants mediate their networks along their mobile trajectories (Schapendonk et. al., 2018; Wissink et al., 2017).

This article argues that the mobility of EE has to be analysed from the perspective of the new trends of mobility that were created after the enlargement of the EU to Eastern Europe (Marcu, 2015a,b). In this framework, mobility of EE shapes different child-parent strategies, which are specific to the needs of support generated at different stages of life: mobility as a strategy to support parents in old age; mobility as a family livelihood strategy; and mobility as a strategy of gratitude and family reunification.

First, mobility as a strategy to support parents in old age is created and interpreted as a way in which individuals organize their linked-lives in relation to their elderly parents. I highlight how people on the move, make decisions in relation to the needs of their parents. Previous 
studies delved into how intergenerational relationships affect social norms (Parreñas, 2005), emphasizing return visits for care (Horn, 2017), or feelings of loneliness of older parents, called ‘orphans pensioners' (King and Vullnetari, 2006). Authors use the concept of 'kin work' (di Leonardo, 1987) or 'stay in touch' (Baldassar, 2007) to study how work is performed within mobile care relationships, and how 'transgenerational care' may be managed from a distance (King et al., 2014). They stress the diversity of activities, such as sending remittances (Pinger, 2010), virtual communications or the role that new communication technologies play in sustaining these interactions, improving and increasing the frequency of economic and emotional exchanges in time-space (Moskal, 2015; Szewczyk, 2015). For instance, drawing on the case of Romanian migrants in Switzerland, Nedelcu and Wyss (2016, p. 203) highlighted that 'being and doing things together at a distance through new information and communication technology are able to create forms of ordinary copresence within mobile families’.

Although geographers (Willis and Yeoh, 2002) have analyzed the daily work entailed in maintaining informal transnational childcare relationships between migrant parents and the children's kin or non-kin caregivers in the country of origin, the interrelationship between mobility and support strategies for older parents throughout the life-course has been scarcely researched (Liu, 2014; Baldassar, 2007). However, in their work about transgenerational care, and drawing on Albanian migrants in Greece, Italy, the UK and in various parts of Albania, King et al., (2014) examine the older generation as caregivers.

Following and intersect with this literature, this paper adds how the intense movement of EEs to/from Spain facilitated by the integration of their countries into the EU helped them to create a mobility strategy to support and improve the quality of life of their elderly parents, both financially and emotionally, and in this way, to link their lives more closely. 
If before the EU integration the children could only visit their elderly parents from time to time, currently, they may visit them several times a year, and support them both financially and emotionally. The elderly parents in turn help their grandchildren to study at foreign universities. This shows, as we shall see, that older people can often be 'the economic pillars of multi-generational families’ (Schröder-Butterfill, 2004).

Second, mobility as a family livelihood strategy is shaped as a life-course interaction between the support that parents transmitted to their children and the support that the children currently offer their parents. Through this interaction, social life -networks, norms and trust- enables participants to act together more effectively to pursue shared objectives', as Putnam (1995, p.664-665) argued. Conceptualizing intergenerational transactions and linkages in mobility, geographers have emphasized the social capital that individuals access and mobilize through their social networks, related to labor market opportunities (Schapendonk, 2015; Mohan and Mohan, 2002). Accordingly, this paper highlights that the effects of social capital on life chances are reflected in intergenerational relations as a possible pathway for how families transmit advantages to their children, manifested by a better education which may improve quality of life.

Conceptualizing the effects of life-course transitions and interaction, Kaufman and Uhlenberg (1998) examine how life-course changes in both generations influence the quality of the relationship that adult children have with their parents. Authors depict the events and transitions highlighting 'the interaction between the individual's social worlds over the lifespan-family’ (Elder, 1994, p. 6). In this context, Sichling (2017) suggests that getting a job and leaving the parental home are key transitions in the progression to adulthood.

Conceptual contributions have pointed to the significance of interactions between life-course developments of related individuals (parents, partners or children), highlighting transnational connections as relevant resources for people in advancing their socio-economic positions 
through overseas education or work (Brooks, 2018; King and Lulle, 2015; Waters, 2005) or financial support as a key source of support exchanged in families (Baldassar, 2007). Following Waters (2005, p. 360), who highlights that 'the symbolic and material implication of overseas education (...) has to be observed transnationally', this article contributes the relationship between mobility and linked-lives as a family livelihood strategy in the country of initial mobility. In line with Baldassar (2007) and Parreñas (2005), I emphasize both the positive aspects (improving the living conditions of their families) and negative feelings and experiences (no parents, forming a family or having a partner) related with family interdependence in mobility as a support strategy.

Third, as a result of intergenerational interaction, mobility as a strategy of gratitude and family reunification emerges as an innovative feature produced by the circuit of mobility. After finishing their studies in EU universities, some of the graduates choose the strategy of practicing labor mobility to other countries, such as Spain.

Concerning the young practicing mobility for studies, King et al., (2010, p.7) noted that it might be a prelude to immigration after the studies have finished. Specifically, in the case of young EEs, although their parents have few resources, they make significant efforts to keep their children in foreign universities (Marcu, 2015a, p.71). This is a strategy of education that, as Waters (2005, 372) following Bourdieu (1996a) argued, 'should be conceived as 'cultural capital', and inextricably linked to middle-class concerns about social reproduction' (Bourdieu, 1996a). Previous studies analyzed the intergenerational relationship highlighting the connections between family members (Mulder et al., 2009; Hopkins and Pain, 2007; Smith, 1998) or classical family reunification, when parents bring their children with them (Remennick, 2013).

Drawing on Waters (2005, p. 368), who highlights the importance of the 'family unit' in providing both a suitable environment and the necessary resources to pursue educational 
opportunities (...) overseas, this article captures the mobility strategy, used by young EEs -as a key element- to support their parents after graduation and bring them to Spain. It is what I call mobility as a strategy of gratitude and family reunification, which has not yet been analyzed, and that is part of the current patterns of mobility practiced by EEs in the enlarged EU. It is important to note that in this circuit of support in mobility, there are also disagreements between members of the same family, as we will see in the case of the EE grandparents who helped their grandchildren by financing their studies abroad. Coulter et al., (2012) raised this important aspect in the framework of mobility centered on the disagreement between family members throughout the life-course.

While many authors have looked into transnational practices of EEs in the enlarged EU (King et al., 2014; Lulle, 2014; Moskal, 2015; Metykova, 2010), few authors have researched the experiences of mobility of EEs in Spain (Petroff, 2016; Marcu, 2015a,b). Some authors analyze the behavior of other groups of immigrants (especially from Latin America) in Spain. For instance, Gualda and Escriva (2014) study diversity in return migration and its impact on old age; while Parella et al., (2013) investigate the upward occupational mobility trajectories of immigrant women performing unskilled work as a first job in Spain.

In order to enhance our comprehension of linked-lives through the life-course, this article thus makes two contributions. First, it expands the concept of linked-lives across the life-course in mobility. Second, it highlights mobility as a support strategy to show how EE mobile children, through their movement, assist their parents both in their origin countries and in Spain. I suggest thinking about the perception that mobility articulates and harmonizes multiple practices of support strategies that link people's lives across the life-course in different ways.

\section{Eastern Europeans in Spain}


The migration/mobility process of EEs in Spain took place in three periods. The first lifecourse stage of migration of EEs (Romanians and Bulgarians) to Spain began in the 1990s, when the borders were closed and it involved lower-middle class people who wanted to improve their economic status (Marcu, 2015b, p. 509). According to Ban (2009, p.132) 'immigrants of the first wave were quintessentially transnational: they worked in the host countries (...) and were not joined by their families'. At the end of this first period, in 20002002, the first mobility networks were created and carried out within the family reunification process. The second life-course stage of EEs in Spain began in 2002 and was marked by the opening up of borders under the Schengen Agreement allowing Romanians and Bulgarians free circulation within the enlarged European Union (EU). This stage is characterized by sizeable mobility for work to Spain accounting for 27 per cent of total departures of Romanians and 22 per cent of Bulgarians (Spanish National Institute for Statistics, 2010). During this period, mobility networks were extended and the mobile population became notably transnational. Finally, the third stage of mobility, taking place from 2007 to the present time, has been marked by Romania's and Bulgaria's entry into the EU, and is characterized by the undisputable concentration of almost 60 per cent of Romanian and Bulgarian migration in Italy and Spain (Ban, 2009). Throughout the last two stages, families began to bring their children born in their origin countries to continue studying in Spain (Marcu, 2015b). Despite the consequences of the economic crisis, which have been widely attributed to the adverse developments in the construction sector, the mobility of EEs to Spain has continued to increase. According to the Spanish Ministry of Labor and Immigration (2018), in 2017, Romanians represented the largest group of foreigners living in Spain, with some 1.030,054 citizens registered, while the Bulgarians registered 190,981 citizens. 
One of the most interesting features of mobility is that it is indecisive because it tries to be in two or several places at the same time and it is unclear which will prevail. In addition, the young people who undertook their mobility process during the last decade change their place of residence easily, adapting quickly to new surroundings. Mobility is thus part of an incomegenerating strategy. Although at the beginning of the migration project, confidence between parents and children may be interrupted, as time passes, a strategy of financial and even emotional support is developed by the children to their parents and vice versa.

Thanks to the new forms of mobility favored by the enlargement of the EU and the free movement of people, in the current context of crisis and unemployment, it is the children who are taking advantage of their work opportunities to support their parents. Therefore, I underline the EEs' capacity to move across several countries to study and/or work, supporting their families through their mobility.

\section{Methodology}

Qualitative methodology was used to carry out this research, with 52 in-depth interviews conducted between January 2015 and September 2016. First, I conducted 15 in-depth interviews with Romanians (8) and Bulgarians (7) (10 women and 5 men) between 40 and 50 years old, resident in Spain (Madrid, Valencia and Barcelona), who return to their countries once or several times a year to help their parents, and to contribute financially to their care. 8 of these interviewees were married at the time of the interview, and four of them had children. Second, I interviewed 15 people (8) Romanians and (7) Bulgarians, (7 women and 8 men) aged between 30 and 35, who finished their studies in Spain and who currently work in other EU countries: Germany (3), the UK (2), Denmark (4), Sweden (3) and France (3). The interviews with this group were carried out in Spain (5) and via Skype (10). Finally, I 
interviewed 15 young Romanians (9) and Bulgarians (6) (9 women and 6 men) aged between 24 and 35, who completed their studies in different European countries: (7) in the UK, (4) in France, (3) in Norway, (2) in Italy and who currently live and work in Spain: (4) Alicante, (5) Tarragona, (3) Lleida and (3) Vigo. Interviewees from these two groups were single at the time of the interview; 5 of them confessed to having broken up with their respective partners. The questions put to the interviewees covered distinct areas. First, participants were asked to provide a brief account of their family and country context before/after their move and their mobility to/from Spain. Second, we discussed their experiences of mobility, the changing nature of their mobility, the way in which they maintain contact with their families, and the strategies they adopt from Spain, or the countries where they work, to support their families in Spain or in their countries of origin. Third, they were asked about their perceptions related to their mobility and lives linked to their parents, and future plans in relation to helping their families.

To complete the fieldwork, during the month of August 2015, 7 in-depth interviews were conducted with the elderly parents of some of the citizens interviewed in Spain, Romania (4) and Bulgaria (3); (4) of them were supported by their children who live in Spain, while (3) of them helped their grandchildren to study abroad.

Interviewees were selected according to the following characteristics: Romanians and Bulgarians of working age, who had moved from their country between 1990 and 2016 and who had spent at least two-three years in Spain. Some of them came to participate in the project through Romanian and Bulgarian associations in Spain, while others came through personal contacts and the subsequent snowball sampling.

Interviews were carried out in Romanian, Bulgarian and Spanish and were recorded with the participants' permission. In this article, the interviewees appear under pseudonyms to ensure their anonymity. I transcribed and translated the interviews, and then coded and analyzed 
them using the qualitative data analysis software Atlas.ti (Version 7.0). The analysis of the information from the standpoint of codes, concepts and categories identified key relations between the data obtained and conclusions reached (Marcu, 2015a, p. 71). Because of the considerable quantity of information, I have used thematic analysis, which has the advantage of adapting to diverse research paradigms, highlighting the experience of the interviewees as a decisive factor in the analysis (Grbich, 2007). As Collins (2016, p. 1171) following Lawson (2000, p. 174) noted, “...migrant stories generated through interviews can reveal the empirical disjuncture between expectations of migration, produced through dominant and pervasive discourses of modernization, and the actual experiences of migrants”.

\section{Mobility as support strategy}

In what follows, I provide an analysis of my findings in relation to three key themes that together characterize the presence of mobility as a support strategy, which is able to link their lives during the life-course: (a) mobility as a strategy to support parents in old age, (b) mobility as a family livelihood strategy; (c) mobility as a strategy of gratitude and family reunification. It is important to note that the strategies work in the same way for both Bulgarians and Romanians.

(a) They are alone and older: mobility as a strategy to support parents in old age

The EE migrants who arrived in Spain in the 1990s and in the early 2000s, and after 2007, are nowadays in their 40s and 50s, and at the time of the interview lived and worked in Spain. They usually practice mobility from Spain to Romania and Bulgaria several times a year, to support their parents who remain in the countries of origin, and who are now confronted with 
old age. Importantly, they are mobile visits, not return ones. For the first time in the recent history of the migration/mobility of EEs Spain, which began after the fall of the dictatorships in EE countries, aging parents and their care became a challenge for their migrants' children. It is important to emphasize that in the EE countries at the beginning of the migration process in the nineties, the lower-middle class families suffered fractures and fragmentation caused by job loss, rising inflation, vulnerability and poverty. In this context, when separation by migration took place, the relationships between children and parents were not very fluid and this fact produced in the parents' feelings of sadness and solitude. They felt, in the words of King and Vullnetari (2006), like ‘orphan pensioners’ abandoned by their children.

Simina told me:

The first four years I could not go to see my parents. I had no papers to travel, the border was closed. Since Romania joined the EU, it is easier to visit my parents and deal with their problems there. Besides, they are now alone and older, and everything is more complicated. They need more help. Every year I travel to Romania at least 3 or 4 times. I remember when I first went to Spain they were not pleased, but now I work in a tourism company, and they are proud of my achievements. (Woman, age 46, Romania)

Simina's discourse highlights that at the beginning of her migration process, the lack of travel documentation and her living conditions in Spain did not allow her to travel to see her parents or support them financially. Nonetheless, at present, migrants can practice mobility and make return visits due to the opening of the borders, the possibility of free movement, and the improvement in their professional careers. Among the 15 interviewees of this first stage, 13 indicated that they had improved their jobs and that at present they work and earn more. Therefore, when individuals got a good job in Spain, when they could cope with daily life, they reconnected with their parents. They began to practice mobility, and here, we can talk 
about the construction of support strategies, focused mainly on financial and personal support to help and improve the quality of life and/or care of their elderly parents. Furthermore, according to data from the National Statistical Institutes of Romania and Bulgaria (2018) the 2017 average pension of a Romanian pensioner was $€ 211$ and that of a Bulgarian pensioner, $€ 206$. Under these conditions, most retirees need help from their children. As is also clear from Simina’s interview, over the years, if children were successful, parents were content and could enjoy their achievements.

This leads to the support strategy associated with the interconnections between communications and emotions, which allows 'being and doing things together' at a distance, as Nedelcu and Wyss (2016, p. 202) argued.

In summer I am always there, to help with the house just in case the living room needs decorating, or the wiring needs repairing, or the water or the barn needs something or other. This is normal. But for me, the most important thing is that the mobile phone and the Internet help me to be close to them. I call them every day. They tell me if they are happy with the lady who cares for them, if they are eating well. In this way, we stay in touch as if I lived there. (Man, age 50, Bulgaria)

Thus the interconnection of mobility and communications are fundamental to offer emotional support when parents become older and dependent. Interviewees manage to maintain 'the kin work' (di Leonardo, 1987), through attempts 'to stay in touch', as 'an aspiration not only to maintain open channels of communication but some level of emotional connection' as Baldassar (2007, p. 387) noted.

This is also confirmed by Maika: 
The years went by, they both became ill. My heart breaks at the thought of them. I call them daily; we are able to see each other through Skype, we are close. Now, I'm going to go to hire a lady to take care of the house. Mobility between Bulgaria and Spain has brought us closer because I can help them both financially and emotionally. I help my parents who in turn, when I could not, helped my daughter to study at the University of Glasgow. They sold their lands for her to fulfill her dream of studying in the UK. (Woman, age 52, Bulgaria)

Maika’s father, who I interviewed in Sofia, confirmed:

She is the light of our life. She lives in Madrid, but she calls us, she finds about ten minutes a day for us, to make us happy. She also helps us with money, although we have our retirement pension, but she wants to improve our life. Some years ago, we also helped with the expenses of her daughter, our granddaughter that studied in a British university. (Man, age 76, Bulgaria)\#

This quote reveals that although the parents remain immobile in their countries, some of them may, as King et al., (2014) argued, actively participate by supporting both their children and grandchildren, becoming 'economic pillars of multi-generational families' (SchröderButterfill, 2004). This fact shows how lives are linked over the life-course, and how strategies to support parents in old age can work in mobility.\#

(b) It's my turn to help them: mobility as a family livelihood strategy

Another type of strategy linked to the first, is the mobility used by the second generation of migrants, to improve their lives and those of their parents who remained in Spain. Before the 
beginning of the crisis, parents were able to pay for the studies of their children in Spain, but at present they are living in precarious conditions of vulnerability.

Importantly, the economic crisis Spain has and still endures has affected the EE migrants deeply: 65 per cent of those living in Spain were unemployed. While women continue to work in domestic service, mostly without an employment contract, 58 per cent of men who worked in the construction sector lost their jobs (Spanish Ministry of Labor and Immigration, 2017). Their children -who are between 30-35 years old and who came to Spain almost 15-20 years ago to reunite with their parents- were unable to find a job in Spain when they finished their studies because of the economic crisis and so began to practice mobility in other EU countries where they can find work and where the salaries are much higher. As Kaufman and Uhlenberg (1998) argued, life-course experiences lived by parents have consequences for their children. From their respective countries of residence, and despite their temporary and unstable work contracts, they may financially support their parents, who continue to live and work in precarious conditions in Spain. In this way, mobility as a family livelihood strategy is constructed.

We may thus capture the interplay between transnational connections and mobility practiced by young people in their attempts to overcome precarity and uncertainty (Rigg et al., 2016), and conceptualized by Bailey et al., (2002, p.138) as 'permanent temporariness' utilized as a strategy for resistance.

Mihnea confessed:

All my life I have tried to escape precariousness and to survive. I lived in Spain for ten years; I studied there. My parents brought me from Romania when the borders were opened and Romania entered the EU. I was 17 years old. Thanks to them, I was able to study in Spain. Now, after finishing my studies, it's my turn to help them. I'm working in the UK. It's a one- 
year contract in the hotel industry, but it's OK, especially since I can help my parents. I send money to Spain every month. My mother managed to keep her job in domestic service, but my father is out of work. (Man, age 31, Romania)

Mihnea’s narrative shows that young people, who practice mobility with temporary contracts, manage to build a strategy to support their families in Spain by means of financial support. There are two factors that arise in the construction of this strategy. On the one hand, emigrating from their countries at an early age and studying in Spain both prepare young people to continue practicing mobility and to cope with its impact on family life. On the other hand, the strategies that their parents used when bringing them to study in a foreign country (in this case Spain) when they were adolescents served as a model for young people to later return that help to their parents. Thus families transmit advantages to their children (Mohan and Mohan, 2002) and as Bourdieu (1996b, p. 23) argued, '[family] plays a decisive role in the reproduction of social order'. Furthermore, as Waters (2005, p. 360) also noted, the acquisition of foreign educational credentials is conceived as part of a more general childcentred family strategy of capital accumulation involving migration and transnational household arrangements'. Consequently, children's mobility positively affects their relationships with their parents who remain in the country of initial mobility, and maintains their linked lives (Findlay et al., 2015).

However, the interviewees also emphasized negative aspects of their mobility. For instance, some of them pointed out that when deciding to apply for work in other countries, they were giving up, for the moment, forming a family or having a partner. And despite the fact that ‘emotional and moral support can be effectively exchanged well across distance’ (Baldassar 2007 p. 391), some of them confessed that they are often alone and lack the emotional support of their parents. 
Vladimir noted:

My parents brought me from Bulgaria when I was 16 years old. We lived in Spain together. For now, I have no partner. I did have one but we broke up because we did not have work. I got a job in a company in Berlin. I send money every month to Spain because my father is currently unemployed. And although I miss my parents, I think I have improved in my life as a professional and as a person. (Man, age 33, Bulgaria)

Vladimir's interview reveals that despite the negative aspects -loneliness, lack of direct moral support- young EEs value their strategy of mobility as a positive factor in their personal growth and in improving the living conditions of their families. The interviewees also pointed out that the integration of their countries into the EU enabled them to fulfill their professional aspirations, since, as European citizens, on the one hand, they may practice mobility in the enlarged EU and, on the other hand, they may be able to help and maintain links with their parents:

What mobility allowed me to do was to study, move and improve myself. If the integration of Romania into the EU had not existed, I would never have been able to study in Spain and take exams in Bucharest for a diplomatic career. Now I am working in Paris. My parents are still in Spain, our second country. Right now, they do not work. (Woman, age 32, Romania)

Mobility, therefore, crosses the lives of EEs who studied in Spain, and helps them look for livelihood strategies to improve both their own situation and that of their families.

And although no interviewee has yet done so, because of the brevity and insecurity of their temporal contracts in the new countries of their mobility, they confessed that they thought about bringing their parents to live with them, if their work situation in Spain did not change. This strategy, however, has worked in the case of young EEs who studied in other EU countries, and who found work in Spain, as we will see below. 
(c) I brought my parents with me: mobility as a strategy of gratitude and family reunification

In Eastern Europe, the crisis of the transition to a market economy, which was accompanied by economic structural change and a dramatic increase in the unemployment rate, highlighted the difficulties faced by lower-middle class families in dealing with everyday life (Marcu, 2015a, p.71; Gregson et al., 2010). Parents of the young belonging to the lower-middle classes have supported their children's studies at considerable financial expense in foreign universities. For these families, as Waters (2005, p.370) noted, 'education was a family (not individual) pursuit and should be understood as part of a wider strategy of household capital accumulation'.

This section reflects on how the mobility of young EEs who studied outside Spain is linked to a life course decision taken previously with the intention of relocating in Spain after graduation and helping their parents to practice mobility and reunite with them. This is part of a strategy that has been anticipated and well planned in the family in advance of mobility for study in another country (Waters, 2005, p.368). Having studied abroad, young people find jobs more easily in Spain, a country that values internationalization and knowledge of the English language (Marcu, 2015a). After finding employment in smaller Spanish cities, they choose to share their lives with their parents by renting cheap apartments and inviting their parents to live with them for a time in Spain. They even try to help them find a job. What they are pursuing is to help their parents to have a better, more 'dignified' life than in their home countries. This is what I call 'mobility as a strategy of gratitude' in response to the financial support received while studying their degrees in other European countries, such as the UK.

When I asked them why they used Spain as a meeting place to live together with their families, Boris said: 
Why Spain? I did Erasmus in Alicante and I learned Spanish. Because of the climate and the good lifestyle, I felt it a good place to live. After finishing my studies in Manchester, I returned and found work in a multinational company. English helps me a lot. I decided to thank my family for all the generosity they had shown me for five years. Since my parents did not have work in Bulgaria, I brought them with me. They wanted to come and live by the sea. Now my mother works as a cleaner in a hotel. (Man, age 27, Bulgaria)

However, as Violeta noted:

I studied in Edinburgh thanks to my grandparents and my parents, who were still in Romania, helping me pay for my stay there. A year ago, I found a job in a Spanish company, where I earn enough. Consequently, I brought my unemployed parents to live with me. However, there is now a great problem with my grandparents. My mother took care of them because they were also helping me with the costs of my studies. Now they are alone and angry with my parents for having left. (Woman, age 25, Romania)

From Violeta's discourse, we can see that there are also tensions and disagreements within the family unit, which affect the linked lives within the framework of the chain of support. This was confirmed by Violeta's grandparents, whom I interviewed in Romania. They told me that although they did not leave their country, they were present and helped Violeta during their mobility project, paying tuition fees and living costs while in a British university. George, who was 84 when I interviewed him, pointed out that:

While we were paying for our granddaughter's degree in Scotland, my daughter came to our house and helped us, she took care of us. But now that our granddaughter has finished her 
studies, they have all gone to live in Spain.This hurts a lot, but I know that she has her family, has made a decision with her family, and we do not want to be a burden to her...(Man, age 84, Romania)

Therefore, in the network of support strategies in mobility, it is important to emphasize the role of the elderly (parents and grandparents) living alone in the countries of origin and participating in the support strategies throughout the life-course (King et al.,2014; SchröderButterfill,2004). Nonetheless, as Coulter et al., (2012, p.17) noted, although the household is the site for migration decision-making, it is the interaction between individuals within the household context that determines the outcome of the mobility process. This shows that it is difficult to make decisions that embrace and satisfy the whole family: grandparents, parents and children. Hence, in linked-lives over the life-course, as Coulter et al., (2012, p. 28) argued, 'the individual sacrifice is often necessary to build household consensus'.

This leads to the role of the emotions which appear in the interviewees' discourse, trying to soften the tensions. They highlight the sadness in the solitude of their grandparents, but they also highlight the happiness with the reunification of the family.

Larisa recognized that:

My mother can no longer take care of my grandparent, because she is here with me. On the one hand, that saddens me and I hope that my grandparents forgive us. But on the other hand, I am happy and I am grateful to her...My mother supports me in everything...I get home from work and find the dinner made. And above all, she is there. I must admit that I have been very happy since they have been here with me. (Woman, age 26, Bulgaria) 
This quote shows that this strategy can also be explained by the exchange between economic support provided by the children and the emotional and moral support provided by the parents. Overall, this strategy is used by the young as a tool for family reunification, and proves how it links with the others, creating a circuit of support strategies -including children, parents and grandparents- in different EU contexts. It has been observed how this circuit of support strategies functions in the framework of the linked-lives throughout the life-course, with Spain as a point of reference.

\section{Conclusions}

Taking the relationship between life-course and linked-lives as a central concern, this article contributes to the advancing geographical literature of mobility, by highlighting the role of support strategies that mobile children, using their resources and skills, offer their parents. Analyzing the interaction between individual mobility and the family unit (Carswell and De Neve, 2013; Waters,2005), I have emphasized the role of mobility in the creation of support strategies. I have argued that each stage of the children's mobility coincident with their lifecourse involves a different strategy for supporting their parents.

First, I found that mobility has a profound and significant impact on the family life of EEs living in and/or practicing mobility to/from Spain. Mobility is able to link people’s lives through the support strategies used depending on the life-course stage (Bailey, 2009; Findlay at al., 2015). In the case studied here, two factors that contribute to the tightening of relationships between individuals and their parents throughout the life-course are analyzed. On the one hand, the opening of the EU borders and the integration of Romania and Bulgaria into the EU (2007), favored both the free mobility of people and the possibility of maintaining closer family relations. On the other hand, the increased mobility across the EU borders 
brought about the creation of mobility as a support strategy. In this way, Spain becomes a place where the support strategies in mobility leave, arrive, and are found, making it a crossroads for EEs who practice mobility in the enlarged EU.

Second, I highlight the changing nature of the practice of mobility which favors people's ability to construct supportive strategies that link lives between children and parents throughout the life-course. Consequently, mobility creates different patterns of child-parents relationships that are specific to the needs generated at different stages of life (Mulder et al., 2009; Thomas et al., 2017). If at the beginning of the mobility project, it was the parents who helped their children, nowadays it is the children who provide support to their parents. These findings contribute to our understanding of the ways in which support exchanges can influence and be shaped by mobility. It also contributes to our understanding about the way in which the chain of support strategies that link the mobile lives in the circuit of mobility along the life-course is completed.

Third, the support strategies created affect both positively and negatively the linked-lives over the life-course stage. On the positive side, the interviewees value the opening of borders, the integration of their countries into the EU and the possibility of practicing mobility, emphasizing the role of the media that facilitates their financial, personal and emotional support. On the negative side, it was observed how people make changes in terms of reorganizing their lives as a consequence of mobility. In the case of the first group, the interviewees experience a whole mixture of feelings including sadness for their parents' illness and their loneliness. When we look at the second group, we note that they postpone the decision to start a family, and have insufficient emotional support when breaking up with their partners and/or being away from their parents. In turn, the interviewees of the third group, despite finding emotional support in their parents, which they value positively, they 
also indicate the situation of their grandparents who supported them throughout their studies in foreign universities and who at present are alone in their countries of origin.

To conclude, I highlight that through mobility individuals construct strategies to develop, maintain and negotiate economic and emotional bonds, both across distances, and directly (Wissing et al., 2017; Schapendonk, 2015). Therefore, through their ability to use their resources and skills, mobile people construct different support strategies to sustain their parents' lives. In doing so, they keep their linked-lives throughout the life-course (Findlay et al., 2015; Bailey, 2009). More research about mobility as a support strategy is needed, to integrate the importance of the children's role in supporting their parents into the study of global mobility, contributing in this manner, to a deeper understanding of the increasingly mobile contemporary society.

\section{References}

Adey, P., Bissell, D., Hannam, K., Merriman, P., Sheller, M., 2013. The Routledge Handbook of Mobilities. Sociology after the Mobilities Turn. Routledge, London.

Baldassar, L., 2007. Transnational families and the provision of moral and emotional support: the relationship between truth and distance. Identities 14(4), 385-409.

Bailey, A. J., 2009. Population geography: life-course matters. Progr. Human Geogr. 33, 40718.

Bailey, A.J., Wright, R.A., Mountz, A., Miyares, I.M., 2002. (Re)producing Salvadoran transnational geographies. Ann. Assoc. Am. Geogr. 92, 125-44.

Ban, C., 2012. Economic Transnationalism and its Ambiguities: The Case of Romanian Migration to Italy. International Migration 50, 129-149.

Bourdieu, P., 1996a. The state nobility: elite schools in the field of power. Stanford University Press, Stanford, CA. 
Bourdieu, P., 1996b. On the Family as a Realized Category. Theory, Cult. Society 13, 19-26.

Brooks, S., 2018. Higher education mobilities: a cross-national European comparison. Geoforum 93, 87-96.

Carswell, G., De Neve, G., 2013. Labouring for global markets: Conceptualising labour agency in global production network. Geoforum 44,62-70.

Collins, F.L., 2016. Migration, the urban periphery, and the politics of migrant lives. Antipode 48, 1167-1186.

Collins, R., 2015. Keeping it in the family? Re-focusing household sustainability. Geoforum 60,22-32.

Coulter, R., van Ham, M., Feijten, P., 2012. Partner (dis)agreement on moving desires and the subsequent moving behaviour of couples. Popul. Space Place 18,16-30.

Cresswell, T., 2006. On the Move. London: Routledge.

Di Leonardo, M., 1987. The female world of cards and holidays: women, families and the work of kinship. Signs 12, 440-53.

Elder, G. H., 1994. Time, human agency, and social change: perspectives on the life course. Social Psychology Quarterly 57, 4-15.

Findlay, A., McCollum, D., Coulter, R., Gayle, V., 2015. New mobilities across the life course: a framework for analysing demographically linked drivers of migration. Popul. Space Place 21, 390-402.

Giele, J. Z., Elder, G.H., 1998. Methods of life course research. Qualitative and quantitative approaches. Sage, Thousand Oaks.

Glick Schiller, N., Basch, L., Szanton Blanc, C., 1995. From immigrant to transmigrant: theorizing transnational migration. Anthropological Quarterly 68, 48-63. 
Grbich, C., 2007. Qualitative Data Analysis: An Introduction. Sage, London.

Gregson, N., Crang, M., Ahamed, F., Akhter, N.,Ferdous, R., 2010. Following things of rubbish value: End-of-life ships, 'chock-chocky’ furniture and the Bangladeshi middle class consumer. Geoforum 41, 846-854.

Gualda, E., Escrivá, A., 2014. Diversity in return migration and its impact on old age: The expectations and experiences of returnees in Huelva (Spain). International Migration 52,178190.

Hank, K., 2007. Proximity and Contacts Between Older Parents and Their Children: A European Comparison. Journal of Marriage and Family 69, 157-173.

Hopkins, P., Pain, R., 2007. Geographies of age: thinking relationally. Area 39, 287-294.

Horn,V., 2017. Migrant family visits and the life course: interrelationships between age, capacity and desire. Global Networks 17,518-536.

Hoang, L.A., Yeoh, B.S.A., Wattie, A.M., 2012. Transnational labour migration and the politics of care in the Southeast Asian family. Geoforum 43, 733-740.

Kaufman, G., Uhlenberg, P., 1998. Effects of life course transitions on the quality of relationships between adult children and their parents. Journal of Marriage and Family 60, 924-938.

King, R., Lulle, A., 2015. Rhythmic Island: Latvian migrants in Guernsey and their enfolded patterns of space-time mobility. Popul. Space Place 21, 599-611.

King, R., Cela, E., Fokkema T., Vullnetari, J., 2014. The migration and well-being of the zero generation: transgenerational care, grandparenting, and loneliness amongst Albanian older people. Popul. Space Place 20,728-38.

King, R. Findlay, A., Ahrens, J., 2010. International Student Mobility Literature Review. Report to HEFCE, and Co-funded by the British Council, UK National Agency for Erasmus. 
King, R., Vullnetari, J., 2006. Orphan pensioners and migrating grandparents: the impact of mass migration on older people in rural Albania. Ageing \& Society 26,783-816.

Kwan, M.P., Schwanen, T., 2016. Geographies of Mobility. Ann. Assoc. Am. Geogr. 106, 243-256.

Lawson, V.A., 2000. Arguments within geographies of movement: The theoretical potential of migrants’ stories. Progr. Human Geogr. 24, 173-189.

Liu, C. 2014. Ageing, migration and familial support in rural China. Geoforum 51, 305-312.

Lulle, A., 2014. Spaces of encounter-displacement: contemporary labour migrants' return visits to Latvia’. Geografiska Annaler B 96(2),127-140.

Marcu, S., 2015a. Uneven mobility experiences: Life-strategy expectations among Eastern European undergraduate students in the UK and Spain. Geoforum 58, 68-75.

Marcu, S., 2015b. From the Marginal Immigrant to the Mobile Citizen: Reconstruction of Identity of Romanian Migrants in Spain. Popul. Space Place 21,506-517.

Metykova, M., 2010. Only a mouse click away from home: transnational practices of Eastern European migrants in the United Kingdom. Social Identities 16,325-338.

Mohan, G., Mohan, J., 2002. Placing Social Capital. Progr. Human Geogr. 26,191-210.

Moret, J., 2017. Mobility capital: Somali migrants' trajectories of (im)mobilities and the negotiation of social inequalities across borders. Geoforum, doi.org/10.1016/j.geoforum.2017.12.002

Moskal, M., 2015. When I think home I think family here and there: Translocal and social ideas of home in narratives of migrant children and young people. Geoforum 58,143-152. Mulder, C.H., van der Meer, M.J., 2009. Geographical distances and support from family members. Popul. Space Place 15, 381-399.

National Institute of Statistics Romania, 2018 
http://www.insse.ro/cms/ro/content/num\%C4\%83rul-de-pensionari-\%C8\%99i-pensia-medielunar\%C4\%83-\%C3\%AEn-trimestrul-iii-2017; (accessed 12. 06. 2018)

National Institute of Statistics Bulgaria, 2018

http://www.nsi.bg/en/content/15281/\%D0\%BC\%D0\%B5\%D1\%82\%D0\%B0\%D0\%B4\%D0

\%B0\%D0\%BD\%D0\%BD\%D0\%B8/labour-cost-survey; (accessed 14. 06. 2018)

Nedelcu, M., Wyss, M., 2016. Doing family’ through ICT-mediated ordinary co-presence: transnational communication practices of Romanian migrants in Switzerland. Global Networks 16(2), 202-218.

Parella, S., Petroff, A., Solé, C., 2013. The Upward Occupational Mobility of Immigrant Women in Spain. J. Ethnic Migrat. Stud. 39(9), 1365-1382.

Parreñas, R.,2005. Long distance intimacy: class, gender and intergenerational relations between mothers and children in Filipino transnational families. Global Networks 5(4),31736.

Petroff, A.,2016.Turning points and transitions in the migratory trajectories of skilled Romanian immigrants in Spain. European Societies 18(5), 438-459.

Pinger, P., 2010. Come back or stay? Spend here or there? Return remittances: the case of Moldova. International Migration 48,142-173.

Putnam, R., 1995.Tuning in, tuning out: the strange disappearance of social capital in America. Political Science and Politics 28, 667-83

Remennick, L., 2013. Transnational lifestyles among Russian Israelis: a follow-up study. Global Networks 13,478-497.

Rigg, J., Oven K.J., Basyal, G.K., Lamichhane, R., 2016. Between a rock and a hard place: Vulnerability and precarity in rural Nepal. Geoforum 76, 63-74. 
Schapendonk, J., van Liempt, I., Schwarz, I Steel, G., 2018. Re-routing migration geographies: Migrants, trajectories and mobility regimes. Geoforum doi.org/10.1016/j.geoforum.2018.06.007

Schapendonk, J., 2015. What if networks move? Dynamic social networking in the context of African migration to Europe. Popul. Space Place 21, 809-819.

Schröder-Butterfill, E., 2004. Inter-generational family support provided by older people in Indonesia. Ageing Soc. 24(4), 497-530.

Sheller, M., Urry, J., 2006. The new mobilities paradigm. Environ. Plan. A 38, 207-226.

Sichling, F., 2017. Diversity on the urban margin: The influence of social networks on the transition to adulthood of disadvantaged immigrant youth. Geoforum doi.org/10.1016/j.geoforum.2017.03.029

Smith, G.C., 1998. Residential separation and patterns of interaction between elderly parents and their adult children. Progr. Human Geogr. 22, 368-84.

Spanish Ministry of Labor and Immigration 2018. https://expinterweb.empleo.gob.es/series/, (accessed 18.06.2018).

Spanish Ministry of Labor and Immigration 2018.

http://extranjeros.empleo.gob.es/es/Estadisticas/operaciones/concertificado/201706/Residente s_Tablas_PR_30-06-2017.pdf (accessed 18.06. 2018).

Spanish National Institute for Statistics 2010.Population Register, national results, 1996- 2009 http://www.ine.es/dyngs/INEbase/en/operacion.htm?c=Estadistica_C\&cid=1254736177012\&

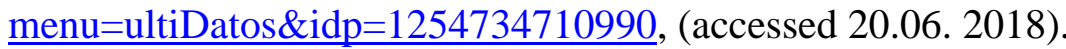

Szewczyk, A., 2015. European Generation of Migration’: Change and agency in the post2004 Polish graduates’ migratory experience Geoforum 6, 153-162. 
Thomas, M.J., Mulder, C.H., Cooke T.J., 2017. Linked lives and constrained spatial mobility: the case of moves related to separation among families with children. Trans. Inst. British Geograph. 42, 597-611.

Visser, K., Bolt, G., van Kempen, R., 2015. A good place to raise your children? The diversity of parents' neighbourhood perceptions and parenting practices in a low-income, multi-ethnic neighbourhood. A case study in Rotterdam. Geoforum 64, 112-120.

Waters, J., 2005. Transnational family strategies and education in the contemporary Chinese diaspora, Global Networks 5(4),359-377.

Willis, K., Yeoh, B., 2002. Gendering transnational communities: a comparison of Singaporean and British migrants in China. Geoforum 33,553-565.

Wissink, M., Düvell, F., Mazzucatto, V., 2017.The evolution of migration trajectories of subSaharan African migrants in Turkey and Greece: the role of changing social networks and critical events. Geoforum doi.org/10.1016/j.geoforum.2017.12.004 